\title{
An Introduction to the Medieval English: The Historical and Literary Context, Traces of Church and Philosophical Movements in the Literature
}

\author{
Esmail Zare Behtash \\ English Language Department, Faculty of Management and Humanities, Chabahar Maritime University, Chabahar, Iran \\ E-mail: behtash@cmu.ac.ir \\ Seyyed Morteza Hashemi Toroujeni (Correspondence author) \\ English Languages Department, Faculty of Management and Humanities, Chabahar Maritime University, Chabahar, Iran \\ E-mail: Hashemi.seyyedmorteza@gmail.com \\ Farzane Safarzade Samani \\ English Language Department, Faculty of Management and Humanities, Chabahar Maritime University, Chabahar, Iran \\ E-mail: F_samani787@yahoo.com
}

Doi:10.7575/aiac.alls.v.8n.1p.143

URL: http://dx.doi.org/10.7575/aiac.alls.v.8n.1p.143
Received: $19 / 10 / 2016$

Accepted: 23/01/2017

\begin{abstract}
The Transition from Greek to medieval philosophy that speculated on religion, nature, metaphysics, human being and society was rather a rough transition in the history of English literature. Although the literature content of this age reflected more religious beliefs, the love and hate relationship of medieval philosophy that was mostly based on the Christianity with Greek civilization was exhibited clearly. The modern philosophical ideologies are the continuation of this period's ideologies. Without a well understanding of the philosophical issues related to this age, it is not possible to understand the modern ones well. The catholic tradition as well as the religious reform against church called Protestantism was organized in this age. In Medieval Period, philosophy and theoretical thoughts related to the Christianity were well-organized and the philosophy, science and theoretical thoughts served religion. Philosophy had different forms and orientations in various stages of this period. One of these philosophical thoughts was the Augustinian philosophy which was strongly in favor of church with its different practices and styles. It used Platonic and Neo-Platonic traditions to prove that faith is the result of divine dispensations, not the result of human will power and wisdom. On the other hand, according to Aquinas, we experience different types of the effects that existed in the world around us. He believed that we assign an effective cause to each effect we experienced around us. Additionally, he claimed that reasoning was the only way to reach the real faith. In fact, philosophy of Medieval Period attempted to prove that religious assertions and ideologists were in search of matching their philosophical beliefs with the beliefs of Christianity. Christianity as the dominant factor in Middle English Literature helped English to be stablished as a literary language.
\end{abstract}

Keywords: Medieval English Literature; Medieval Philosophy; Augustinian Theology; Aquinas theology

\section{Medieval English}

The Middle Age is a thousand-year period in the European history. Scholars mention the beginning and the end of this period as $5^{\text {th }}$ and late of the $15^{\text {th }}$ centuries $A D$, respectively. The end of this period is coincident with the renaissance age. Since this period is between two Greek-Roman and Modern periods, it is called Middle Age by historians (Baugh \& Cable, 2002). In order to reflect the effect of Greek philosophers' performance on the philosophers of the Middle Age, some historians draw back the beginning of the Age to the first or $2^{\text {nd }}$ centuries. Furthermore, some others believe that the beginning of the Middle Age and Christianity are contemporaneous, and because of this coincidence, the thought and reason of this period is called the Christian thought. Historians described this age with the preserving movement and continued emigration of other nations to the land. In the new West historiography, this one thousandyear period is mentioned as the medieval history of Europe. In other words, the Middle Age is a period in European history which separates the ancient time from the modern one ( Wallace, 1999).

Medieval literature was done by hand. The period began and ended with the unwelcomed arrival of two conquerors including the conquest of Normans in1066, and the printing press in 1476. English literature survived the first conquest with difficulty. When the first printed English books appeared, the phase of Middle English was virtually over. As a result of emerging printing press, the language had assumed its modern form except in spelling layer. A distinctive 
stylistic feature of the period was a rapid expansion in the number of words which often entered the language from Latin and mostly from French (Behtash, 2012). English literature of Middle Age is a comprehensive and wide topic that includes necessarily all the written works available in Europe and beyond during the Middle Age. The Western and Central Europe dominated by Roman Catholic Church as well as the other parts of Europe never Romanized spoke in Latin that was language of Roman Catholic Church. That was because Church was virtually the only source of education. Furthermore, Latin language was the common language for medieval writings. But the condition in Eastern Europe was completely different. The Eastern Europe which was under the control of the Eastern Roman Empire and the Eastern Orthodox Church made the languages of Old Church i.e. Slavonic and Greek, the dominant languages (Horobin \& Smith, 2002).

The special characteristic of the society in which languages of Old Church were used was that the vernaculars of common people were used even to create literary works. Writings such as the Beowulf (c. 700-1000 and c. 975-1010 $\mathrm{AD}$ for date of poem and date of manuscript, respectively), the Middle High German Nibelungenlied (The Song of the Nibelungs, written approximately between 1180 and 1210 AD by an unknown Austrian), and the Old French Chanson de Roland (between 1040 and 1115) are well-known examples of such works. Although the available versions of the aforementioned epics are generally considered the works of individual poets, the poems that are from anonymous poets are based on their peoples' older oral traditions. The Works of literature of this age which are often grouped by place of origin, language, and genre were composed of religious writings as well as temporal and non-spiritual works ( Wallace, 1999). In this study, the characteristics of language, poem, society, different types of writing and literary works of Middle Age are examined. And, because some factors such as Church, the concept of chivalry, philosophical movements, and different theologies were dominant factors in the philosophy of the Middle Age, these factors and their effects on the medieval literature are reviewed briefly. The Church was the most dominant institution in medieval life and its religious observances gave shape to the literary works. Consequently, its pervading effect on the literature of this age can be observed clearly. For example, the mainstream religious belief about ethics can be traced in some poems and epics. In this study, in addition to the historical context of medieval age in which literary works has been developed, we examine the content of some medieval works in which the influence of the Church is evident.

The modern English language is the result of several centuries of development during its full of ups and downs history. For example, social, political and cultural forces in the history of English have profoundly influenced both people and language. The recognizable contact between English and Latin civilization that happened in 597 by Roman Christianizing of Britain contributed to the addition of large number of vocabulary to the language. Furthermore, the conquest of Scandinavian leaded to the combination of two people and languages. After the invasion of Normans, English language reduced to the main language of lower classes of the society for almost two centuries while the nobles used French as the high prestigious language in the society. After several centuries, when the English language repossessed its superiority in English societies, it was the language that was profoundly changed in both grammar and vocabulary from what it had been in 1066. For example, several grammatical structures including a "core", and a "periphery" that are usually brought into a language through processes such as historical development or borrowing (Vivian, 1996) have been commonly used in English language. As it was mentioned in later paragraph, after the invasion of England by French Normans, Old English was suppressed in the society, culture and literature of the country. Consequently, the French governors of the country replaced English with the Norman French language and, consequently, French became the language of poems and literatures in England (Baugh \& Cable, 2002). Latin as one of the languages used in the country was the language of science and academic communities. After many years, although English language regained its values, it lost many grammatical features which resulted in phonetic changes. When English language had been enhanced for another time, many French and Latin words and expressions were found as loan words (Horobin \& Smith, 2002).

However, English language survived and was spoken among the defeated Anglo-Saxons who were the peasant class of the society under the control of French Normans who was spread out into the countryside to take possession of the lands and estates. Consequently, French Normans started to learn English language of necessity gradually. After some years, in $14^{\text {th }}$ century, English appeared as the dominant language in the society, but it was very different from the Old English language used by Anglo-Saxon. In fact, co-existence of French Norman language and emerging English were known as Middle English (Algeo, 2010). Both grammar and vocabulary levels of Medieval English language (1150-1500) were impressively influenced by some factors such as changing from one language to another, using languages other than English, and extensive changes in English language use. In fact, due to the existence of a wide range of these changes both in grammar and lexicon of the language, it is not easy to say that the change of which category was more impressive. Actually, the changes happened in the grammatical layer of English caused the extremely inflected English to be reduced to a highly analytic language. Furthermore, the changes in vocabulary domain of English caused many Old-English words to be dropped from the lexicon. Consequently, several thousands of words from French and Latin languages were added to it. The range of changes was so vast that English language was learned like a foreign language at the beginning of the period. Actually, the language looked like modern English language at the end of this period. Some changes in two layers of word and grammar were shown statistically by some scholars (e.g. Fries, 1940; Malone, 1930; Moore, 1927 \& 1928).

Before the invasion of French Normans, English society and literature were more oral. As a result of the Norman Conquest, the oral tradition of English language and society that persisted in the oral habits of mind shaped into being more literate. In spite of the increasing significance of written documents, oral tradition survived as the critical component of medieval society and literature. The persistence of the society with orality was due to the limited practical 
literacy skills of those people who dealt with the official affairs. Because the oral tradition of medieval English was not easy to define and understand, it has been extremely studied so far by scholars (Foley, 1985 \& 2002). Actually, the Norman Conquest is the starting point when several important social, political, cultural and linguistic changes were brought about in English language. By the way, the oral poetics as one of the components of oral tradition collection survived the Conquest and remained somehow unchanged.

The poems of the Middle Age have some common points with the ancient English traditions. Some of them are phonetic similarities and four pressure verses. "Piers Plowman" is one of the well-known and standout examples of this type that might be written by William Langland (c.1332-c.1400). It is a long, emotional and objective work of art that deals with some issues such as poor people, greed of rich and sinning of people. However, the Christian beliefs such as earthy life and "Afterlife and oneness with God" or even the mixture of these two concepts were the main themes of this literary work. This long poem is comparable with another work of Christian fiction called "Divine Comedy" written by Dante. The common point between these two works is that both of them emphasized on the Divine compassionate and the compassionate factor on earth (Abrams, 1979). The "Pearl" is another poem of this kind which is shorter than the Piers Plowman. This poem is more artistic and literal than the previous one. The Pearl is an elegy for the death of a young child and praises the childish innocence in the Divine court. At the end of this work, an influencing and impressive image of Paradise and also awakening from a dream is presented. In fact, getting human beings with the God is the most important feature of this poem and also the other writings of late Middle Age (Amodio, 2000). Then, the manifestation of religious beliefs is so clear in the aforementioned poems.

In the medieval period, Anglo-Saxon society which was king retainer evolved into the feudalism structure gradually. Feudalism organized the society based on three main estates: these estates included clergymen, noblemen, and the peasant. This kind of social ranking was believed to be a part of what was called Great Chain of Being. The Great Chain of Being that was confirmed by some great scholars such as Plato, Aristotle and Plotinus was a medieval metaphor to describe the social hierarchy of society (Gilson, 1931) which was believed to be created by God. The chain includes God, angels, demons, some other creatures such as stars and moon, and the kings, princes, nobles, men, wild animals, domesticated animals and others at the end of this chain or pyramid. In fact, hierarchical arrangement of feudalism provided the society of Middle Age with three social orders including the clergy, the nobility, and commoner. But another social class, called merchant middle class was developed in developing countries in late $14^{\text {th }}$ century ( Miller \& Hatcher, 1978). By examining the literary works of Middle Age, it can be found out that writings of this age are categorized according to the content and subjects they were written. Generally, two types of writings including religious and non-spiritual or secular are known for this age. In the following paragraphs the two kinds of writings are discussed briefly.

\subsection{Religious Writings}

The most important philosophical influence of the Medieval English was from the Church, which dominated the life and literature in the period. Christian's influence on values, beliefs, and practices of Western culture was abundant and it well ingrained into the flourishing society of today. In fact, in dealing with all sides and aspects of Middle English, traces of religion, particularly church, can be seen. Influence of the Church on English Literature is so clear that only a few works can be found without the religious content (Horobin \& Smith, 2002).

Christianity was the most powerful force in medieval society. People were members of the church from their birth and they had never the choice of denomination due to dominance of the Church. Spiritual works and theological form of literature were the dominant forms that were typically found in the Middle Age. Catholic clerics were the only scholarly persons that were observed as the intellectual center of society in the Middle Age. The literature of these persons was produced in the greatest quantity. Countless psalms and hymns such as liturgical and para-liturgical forms as well as other different forms of spiritual songs sung by Christians to praise God survived from this period. The liturgy itself was not in fixed form, and numerous competing missals set out individual conceptions of the order of the mass (William, 1998). Some well-known religious scholars like Pierre Abelard (1079-1142), Anselm of Canterbury (10331109) and Thomas Aquinas (1225-1274) wrote some philosophical and theological treatises. In their lengthy theological and philosophical writings, they often attempted to reconcile the teachings of the Greek and Roman pagan authors with the doctrines of the Church. Hagiographies, or "lives of the saints", were also frequently written, as an encouragement to the devout and a warning to others (Gilson, 1931). One of the works that reached such popularity is the Golden Legend of Jacobus de Voragine. That was reportedly read more often than the Bible. Francis of Assisi was renowned for his prolific output, and consequently, his Franciscan followers frequently wrote poetry as an expression of their piety (Gilson, 1938).

The two most powerful Latin poems were Die Irae and Stabat Mater which were on religious subjects. Goliardic poetry (four-line stanzas of satiric verse) was an art form used by some clerics to express dissent. Mystery plays which were not produced by clerics were the only widespread religious writings of that time. Mystery or miracle plays are among earliest formally developed plays in Medieval Age (Abrams, 1979). These plays focused on the representation of Bible stories on the subjects such as Creation, Adam and Eve, the murder of Abel, and the doomsday. The texts of these plays were often controlled by the local craft guilds that were the main administrative factors to control and manage the written texts of such plays. It is worth mentioning that, in the Middle Age, due to the popularity of oral tradition, the popular mystery plays were usually performed orally in nights and lasted all the nights. Here, it should be mentioned that the religious literature of Middle Age appeared in several genres (Abrams, 1979) including: a) Devotional books, b) Books of Hours that were collections of prayers and devotionals writings, c) Sermons on religious or moral subjects, d) 
Psalters including the books that covered psalms and other devotional materials, e) Missals including books containing the prayers and other texts that were read during the celebration of mass throughout the year, f) Breviaries that were the books containing prayers and instructions for celebrating mass, g) Hagiographies or stories of the lives of saints, h) Medieval drama, i) Mystery plays that depicted events from the Bible and served a predominantly illiterate population, j) Morality Plays, often allegories, that intended to teach a moral lesson and served a predominantly illiterate population.

\subsection{Non-Religious Writings}

Actually, most of the English literary works were greatly impressed by religion predominantly based on the Christianity and the Bible until the second half of the $14^{\text {th }}$ century. Since then, it can be seen that some non-religious works such as Sir Gawain and the green Knight, d'arthur Morte by Thomas Malory and Canterbury Tales by Jeffrey Chaucer started to appear gradually in the literature. Chaucer (1342-1400), the father of English literature, is the only medieval English poet who has been read continuously from his time down to ours. There are good reasons for this. The best reason is his greatness: he is the great poet of his age and one of the 'big four' of English literature; the other three are Shakespeare, Milton and Dickens. Another reason is the accidental fact that Chaucer happened to write in the dialectical medieval English from which standard modern English was derived. It would not be surprising if Chaucer had written all his works in French. His poetry was intended for an audience undoubtedly fluent in French. Use of English for a poet to proclaim himself an 'English poet' was still a bold and uprising move (Behtash, 2012). The available works of Chaucer confirm the fact the contents are some of the greatest and most original poetry in the English literature. Chaucer's great achievement was to establish English as a major literary language, and his poetry has been loved for generations for its humanity and humor (Abrams, 1979).

The type of non-religious or secular literature was not produced in equal quantity as religious literature in this Middle Age. It means that the quantity of religious works and writings was much more than secular ones. This issue emphasized the importance of the religious works and the influence of Church on the literary trends of this age ( Fichtenau, 1992). Some secular works were produced at that time. Much of that quantity has survived and a rich corpus of secular works is available now. The most prominent Jewish authors of non-religious poetry in the Middle Age were "Solomon ibn Gabirol" and "Yehuda Halevi", both of whom were also renowned for religious poets ( Wallace, 1999). It is worth mentioning that the subject of "courtly love" became also important in the $11^{\text {th }}$ century, especially in the Romance languages. In addition to the epic poems such as Beowulf and Nibelungenlied in the Germanic tradition, courtly romances in the tradition of the roman courtois such as Digenis Acritas which deal with the Matter of Britain and the Matter of Rome and epic poems in the tradition of the chanson de geste gained enormous popularity. Travel literature and political poetry written towards the end of this period were also popular (Algeo, 2010).

The power and influence of the church at that time provided the Church with the opportunity to let just its trusted people (i.e. priests and clergymen) to produce literary texts. With this approach, the Church could take the control of literature to impose ideas and beliefs on people. But here, to elucidate and explain the effects of religion on the Literature and to find the sources of these effects, first it is required to deal with the beliefs and ideas dominated the Church. Among them, the dominant philosophy or philosophies can be mentioned. In fact, the philosophy was the best way to furbish the beliefs of Church and impose them on people. On the other hand, the philosophy helped to solve those kinds of problems which the Church was unable to deal with rationally. Then, the philosophies and philosophers were good tools to make the religious beliefs seem reasonable and make them influential. In the following paragraphs, first the effects of philosophy on religion and Church are discussed and then the religion and how the literature of that time is formed are dealt with (Gilson, 1931).

\section{Religion and Philosophy}

Medieval philosophy is traditionally considered as the philosophy of Western Europe between two eras including decline of classic pagan and the Renaissance. Since it is not possible to examine such a broad topic in details in a single article, the present study articulates some of the overall outline of the philosophy and the related movements of medieval period. The Roman Catholic Church was the most important philosophical influence of the Middle which dominated life and literature. In this section, the researcher of the current study analyzed the relationship between religion and philosophy and investigated their influences on some of the literature content of Middle Age.

After the Christianity swapped through the Roman Empire, the popular Greek philosophy was replaced with the medieval philosophy. In fact, Greek thinkers had dramatic influences on the story of philosophy in the Europe of that time and the new philosophers were under tremendous influence of Greek thoughts such as Aristotle and Plotinus. When the Christianity brought about its new ways of thinking about the critical themes of a monotheistic God, its kingdom, and intellectual tradition to the society by offering Bible, the severe conflict began between the religion and cultural and philosophical institutions. The conflict between Christianity and the philosophical institutions resulted in destroying schools of philosophy. Moreover, what we can find within the philosophy of Medieval Age is a kind of compatibility between Greek way of thinking and Christianity. Some critical issues of middle ages such as the relationship between reason and faith attracted much attention of Christian, Muslim and also Jewish philosophers. The church was in favor of faith only-position. For example, Church theologian Tertullian (155-230 CE) was the strictest supporter of faith-only position in Medieval Age.

Augustine (354-430) was the pioneer of medieval philosophy. This school of philosophy emphasized that knowledge and moral goodness should be achieved through divine awareness and loving God, respectively. In fact, Augustine's 
school of philosophy was based on his Confessions that was actually his life's details. This school of philosophy is today considered a classic of world literature. The philosophic-religious approach of Saint Agustin to religious scripts and also the theological philosophy of Thomas Aquinas helped to address many economic and political crises of the era. Regarding to the fact that the people of the era were deprived of individual or public freedom, such that it was believed that real freedom never existed; priests could handle and address political and social problems by their specific interpretation of these philosophies. With these interpretations, they were able to control people by associating people's pain and sorrow to Christianity. For example, Erich Fromm (1941) once stated that although humanity was completely deprived of freedom and only excessive pain was gifted to people, there were churches that alleviated the tolerance of pain by justifying the pains as the consequences of sins and taboos, individually or collectively (Fromm, 1941).

In this section, the process of turning from pure religion to the ideologies regarding the philosophical movements of the West is analyzed and their role and effect, appeared as the Christian theology, is put under discussion. Naturally, among the movements that affected the evolution of the Christian theology, the significance of Scholastic Philosophy cannot be overlooked. In this context, we study two important and influential figures of Christian theology with two different and rather contrasting approaches. For this purpose, it is necessary to deal with ideological and philosophical trends with distinct philosophical system which are unrelated to Christian framework. These ideological and philosophical trends had great influence on Christian ideologies. Here, we study two major and mainstream ideological movements in the field of traditional theologies of Middle Age that were greatly impressed by Greek philosophical system.

In the history of Christian theology, two religious and ideological trends were leaded by two scholastic philosophers with two different epistemological orientations. One of these theologians was Saint Agustin (born 430), and the other was Thomas Aquinas (1224-1274), both of them were theological philosophers of the West and were influenced by major Greek philosophers such as Plato and Aristotle who had greatly influenced the ideological trends of the Christianity. Meanwhile, Agustin was a significant figure as the greatest author and scholar of the Christianity in the West, and due to his faith-oriented approach, he was a notable figure in the religious ideological movements. He was also the stand-out religious philosopher that had greatly influenced the theology of the Middle Age (Weber, 1908).

\subsection{Augustinian Theology}

The first movement of two religious philosophical schools of Christian theology was led by Augustine, who was a religious philosopher with specific epistemological viewpoints. Inspired and influenced by the Platonic philosophy, Augustine opened a new chapter in the Christian religious school of thought for the religious members of the society. Christianity started a rapid incorporation into the Platonic doctrine and philosophy that expressed special views on the human soul. The philosophy and the religion were very congenial to each other in their respective teachings (whitehead, 1967). According to Whitehead (1967), the mixture of the early Christian religious systems and Platonic philosophy principles, which was a blessing by itself, provided Western races with an impressive social goal that was expressed intelligently and was closely associated with sudden and random manifestations of the emotional force". Christianity dissolved the Platonic essence of humanity soul while the philosophical and religious teachings complied with each other. In fact, the Platonic philosophy brought about a new life to the early form of Christianity. Based on the Platonic philosophical teachings, Christianity could free itself from the skepticism of the time. Platonic philosophy presented a new theory and perception to the Augustinian thoughts. This change and improvement in Augustinian thoughts could manifest theology in a specific epistemological illuminated viewpoint that was based on vision and insight. With respect to the differences between Platonic Philosophy and Christian Ideology of Augustine, the distinctions between Platonic ideology and Augustine orientation are worth considering more. Regarding to the differences between the Platonic philosophies with Christian ideology, it can be stated that Agustin believed that Platonism is the best way to achieve Christian faith. However, there are some differences between Platonism and Augustinian theology. According to the Augustinian theology, human cannot reach God- this definite entity of Christianity-, while in Platonic philosophy, human is aided by the rational wisdom- this great exclusive gift of humanity - to reach the other world (i.e. Plato's allegory of the cave). Furthermore, for a faithful Christian such as the African saint- Agustin- no epistemology exists except human wisdom, and he enjoys the real human rationality. What we call human wisdom is, in fact, the conscience and illumination that God has bestowed upon human. Augustine ideology should be considered as the earliest and first classical evidence and sample of eclectic thought through which the Platonic concepts and religious tradition with new combination are used to solve the dialectical difficulties of Christian tradition. Some believed that differences between Plato and Agustin were undeniable and unsolvable (Gilson, 1931). Agustin's statements should be viewed and interpreted by considering his religious experiential perceptions. This is the issue that might not give new meanings to every concept he utilized, but might give them new perspectives. Between what the ideologists of the middle age referred to as the 'Journey of the soul towards God' and what Plato referred to as 'the Ascension of the soul to the rational world', there exists a massive chasm. In this respect, Whitehead (1967) declared that the religious story was more specific than the philosophical story". Agustin's opinion about the principles that he introduced was different from that of those from Plato". This is partially because Agustin demanded religious concepts and matters to help Platonic Philosophy and consequently he could establish a solid insight in ontology and mystical theology. "Saint Agustin evolved his opinions. He not only eternized the severity of influential emotion containing religion change, but also maintained his foundation according to his new exact principles and remained Platonic.

\subsection{Aquinas Theology}

Another major movement of the Christian Theology is one that has been profoundly influenced by Greek philosophy. By adopting a specific kind of the Greek philosophy, this movement has practically confronted the faith-oriented 
approach of Agustin. The bold figure of this movement is Thomas Aquinas that has leaded this movement by being inspired by Aristotle philosophy. He was a professor of Sacred Theology, and moral philosopher. He was a catholic moralist whose ability to sieve the philosophy of the pagan Greek philosopher made him so popular. His classics writings were greatly influenced by the doctrine of Catholicism. He could achieve new horizons in religion philosophy. Due to the Aristotelian philosophical concepts, he could discuss the religious and theological concepts of Christianity rationally and reasonably. Then, it is of prime importance to consider Thomas Aquinas as the distinctive character of the Middle Age who had a great influence on the other modern and new religious trends. As Lucas (1943) states that Aquinas' greatness is due to his better understanding and analyzing the Aristotelian philosophy and ideology than his contemporary philosophers. His theology became popular and gained more strength in the $2^{\text {nd }}$ and $3^{\text {rd }}$ centuries through decision of many people to become church fathers, bishops and theologians. He could also match the Aristotelian philosophy with the Christian thought. He provided a trusty intellectual foundation for the culture of middle and modern centuries by combining the science and Aristotelian philosophy or Christianity religious ideas and thoughts. According to Aquinas, the perfect truth of faith is known via virtue of reason and wisdom. Furthermore, faith and charity were considered preconditions for the achievement of this wisdom that should be met. By examining some of the writings of Thomas Aquinas, we find out that he was interested in studying and applying Aristotelian model to his reasoning. Additionally, it is discovered that Aquinas Theology

\section{The Christianity and English Literature}

Old English was created by the invasion of German tribes to the today's England in the $5^{\text {th }}$ century. These tribes and nations provided their language as well as their literary traditions to the poetry of Britain. These traditions were remained in Britain until the invasion of French Normans. Since, in Middle Age, literacy was mainly restricted to the most powerful men of society such as servants of the church, it would not be surprising that most of Old English literature and the related works dealt with religious themes. Moreover, it is natural to see that most of those works were from Latin sources (Algeo, 2010).

The main popular genre that was written by most of the renowned writers such as Minucius Felix, Tertullian, Arnobius, and Lactantius until the end of the $3^{\text {rd }}$ century was apologetics genre (justifications of Christianity). In $4^{\text {th }}$ century, the Bible was rendered into Latin language by St Jerome. The production of this translation that increased the use of Latin language among the $4^{\text {th }}$ century's Church Fathers such as Ambrose, and St. Augustine of Hippo was an edition known as the Vulgate. Much of what they wrote was concerned with the theological controversies of the time, such as Arianism (Abrams, 1979). It also seems that the most parts of Old English Literature were written to be recited and read by the story tellers and scopes orally especially in night meetings. The epic story tellers read or sang the literature in specific musical rows with harp. These poems and lyrics written on the futility of life and inability of human against the fate and destiny were read and sung audaciously with grief. Beowulf, the famous epic, and Cynewulf and Caedmon, the two poets who composed poems based on the Gospel as well as the religious traditions and narrations are among those works that were sung by observing special conditions. The Beowulf epic is the great and magnificent sample of poem in old English Literature. Beowulf is a Scandinavian hero who battled and fought with Grendel, Grendel's mother, and the Dragon. He was not only a champion, but also the Savior and supporter of people. This (the Savior) is what the vast majority of Old English Literature is devoted to in ancient time. Actually, Beowulf epic depicts the heroic deeds of a human that is larger than life. Beowulf prominently occupies a place in the national lore of the people that created it (Horobin \& Smith, 2002).

Regarding the vital role of Church to define, determine and control the religious beliefs of people as well as to create a literature based on those religious beliefs and concepts by the clergies and priests, the existence of myths and heroes such as those in Beowulf were inevitable in the literature of that time. Moreover, one of the other characteristics of the Beowulf based on the religious beliefs is to reduce the role of fatalism and to increase the role of human power and free will. Moreover, the Christians' belief in dependence on God is apparently manifested in this epic. However, this characteristic is seen in many other stories remained from that time, and this is because most of those works were prescribed and written by Christian monks. Most of the literary works of that time were written by the religionists themselves and that happened after the ancient English people abandoned their old religious beliefs.

The oldest poet of English Language is Caedmon who lived in $7^{\text {th }}$ century. Saint Bede the Venerable, the Christian clergy of $8^{\text {th }}$ century remembered him and wrote that Caedmon was an illiterate shepherd. He continued that one night he heard a voice commanded him to write the story of the creation, and so he did. Saint Bede wrote the poem of Caedmon in his book (as prose). In addition to the long religious poems which we have noted earlier, some songs are remained from that time. And most old Anglo-Saxons believed that those kinds of songs bore deplorable and unfortunate situations except Christian theology. The Wanderer and the Seafarer are two great examples of those kinds of songs. In this period, the literary prose mostly included religious writings. One of the greatest known ancient proses called Historia Ecclesiastica Gentis Anglorum (the Christian history of English nation) was written in Latin by Saint Bede. It was written in $8^{\text {th }}$ century. As mentioned earlier, in the age of Medieval English Literature, German tribes and nations provided their language as well as their literary traditions to the poetry of Britain and those traditions were remained in Britain until the invasion of French Normans.

In fact, the invasion of French Normans to England is taken as the beginning point of the Middle English Age. The related literature covered the period from 1066 to 1485. It was the time through which the pure tradition in English literature and history began to appear. Among the changes of the literature occurred in this age, legends of knights, portraits of medieval society, and love poetry can be mentioned. The first English women poet appeared in this age. The 
most well-known poets of this age are Geffrey Chaucer, John Gower and Skelton (Abrams, 1979). Religious concepts and trends can also be seen in the works of Chaucer. He intelligently criticized the practices of Church in the society and towards people in his Canterbury tales. According to Wallace, Chaucer (d. 1400)'s imitation of French and Italian poetry based on his own native speech and vernacular demonstrated a transition from English. Furthermore, it indicated the change that was taking place in the status of English. Additionally, the works of Chaucer considerably improved English prestige as a vehicle for literature of high ambition. The poets of $15^{\text {th }}$ called him reviver and decorator of English language and consequently, the writers of later centuries called him the English Homer and the father of English poetry (Wallace, 1999).

To understand and know the works of the writers of Middle English literature better, the social-historical period of that age is worth taking into account. Some important events including consolidation of English as the main language of England, the influence of Catholic Church on the society, the hundred years' war between Britain and French happened in England and Europe differentiate this age from the other ages. It can be said that two of these events had great influence on the writers of the age: establishment of English as the main language in England and the influence the Catholic Church had on the society and its power and dominance over the country (Algeo, 2010).

Due to the dominance of France and Germany over the England and English people during some decades in the Middle Age, English was profoundly influenced by the languages of those two countries. Old English literature has much in common with Germanic literature. The root of these similarities can be searched into the political and social dominance of Germanic countries over England and the influences their literatures had on English literatures. As instance, the Christian as well as heroic stories is the common point between English and Germanic literatures. Germanic heroic poems were used to describe the current events of the society and were performed predominantly orally in alliterative verses of different meetings. For example, the Battle of Brunaburh as a kind of traditional alliterative verse can be mentioned. This poem is about the political victory of England over the Danes. These pieces of literary works indicated that both clergy and laity in the Christian era were inspired by the values of Germanic society. And since Latin was the language of the Church, it had also great influences on English language and behavior of people. Then, the influences of Germanic, French, and Latin languages on English are of extremely importance (Bennett \& Smithers, 1968). During the Middle Age, if the people did not follow what the Church said, they believed that they would get punished by God. In fact, God was at the center of the Universe. In spite of the existence of such beliefs in Middle Age, the writers of this period worked to create lyric poems and dramas related to Church and its role in society in which the people lived. Mother Julian of Norwich, for example, wrote about divine and the power and influence of God during the Middle Ages.

\section{The Church}

The Catholic Church was the most significant philosophical trend that dominated English literature and society of Middle Age. In spite of the dominance of the Church on the society, some critical works such as Canterbury Tales that criticized the Church with a sense of humor were created in the English of Middle Age. Some events such as outbreak of the Black Death happened in Middle Age impressively influenced daily life of the people and the philosophy of the age. These events helped convince people that they are punished by God. In fact, church was the most powerful force in the society of Middle Age (Algeo, 2010). Even without considering such awesome events, Middle Age was a dangerous and unhealthy time and it was usual for the people of entire village, for example, to die of plague. Women often lost their lives in childbirth; the mortality rate of children and infants was high, life expectancies were short and sanitary conditions were nonexistence. Even the deep and wide moats dug around the castles that seemed marvelous in modern world were used as open sewers. Under these conditions, people were expected to live with a persistent sense of mortality and, for many, a devout grasp on the Church's promise of Heaven. The role of Church to justify all these hardships was emphasized. Life on earth was viewed as a vale of tears; a hardship should be endured until one reached the afterlife. It was believed that physical disabilities and ailments such as Black Death which caused the death of around $1 / 3$ of the country population as well as the hardships people encountered in their lives was the judgment of God for the sins they did (Zeigler, 2006).

The image of wheel of fortune as the most significant and well-known metaphor used in Middle Age was provided for society by religion and Church. It pictured life as a wheel of chance where an individual might be on top one minute and on the bottom the next (Alston, 1998). Actually this image of life referred to the point that life was unpredictable and precarious. The monk, for example, in Chaucer's Canterbury Tales talks exactly about the issue that one might enjoy good fortune in life until a turn of the wheel brought him tragedy. Thus, the role of church was to justify the hardships of life by bringing an image of punishment for the hardships due to sins. And this justification eased the endurance of the hardships and punishments (Abrams, 1979). In the Middle Age, the Roman Catholic Church was the central institution around which the lives were organized. In fact, at the time when the Roman Catholic Church dominated the society as the main social base and the owner of power, everyone was a member of the Church by default. If someone was not Christian, s/he was undoubtedly Muslim or Jewish. Of course, at that time, there was not much Muslim in England and the Jewish were expelled from the country by Edward I. In England, just the Christians were respected, and this kind of separation of people according to their religion which was known as "Us vs. Them" mentality of the religious was manifested in all the literature of the era. Dominance of the Catholic Church in England lasted for nine whole centuries but this dominance was broken off by advent of Protestant Reformation in $16^{\text {th }}$ century. The religious beliefs of the Catholic Church were omnipresent in people's life during all the period. In the society of Catholic Church, people had to pay about $10 \%$ of their yearly outcome as tax (called tithe) to the Church. This donation 
was not voluntary and the Church received money for all the services (even religious ones) it provided for the people. Some of this obligatory tax was spent to cloth and feed the poor, but lots of money collected as donation also went to lining the pockets of the Church's upper echelon. However, this hypocrisy is severely criticized in many literary texts of the era. In Medieval England, in addition to the taxes on church, land and taxes on personal property, taxes on trade was also introduced (Nigel, 2000).

One of the figures who criticized the performance and practices of Church is Geoffrey Chaucer. He criticized church intelligently by providing some characters such as the Friar, the Summoner, and the pardoner in his Canterbury Tales. In this work, we see that the people, who gathered at the Tabard Inn in preparation for a pilgrimage to Canterbury to receive the blessings of the English martyr St. Thomas à Becket, were willing to pay money for the services they received from the aforementioned shady characters ( Wallace, 1999). It may be because people in the Middle Ages were terrified of going to Hell for their sins, and the only center for avoiding this thoroughly unpleasant possibility and abating their fear was the Catholic Church. Actually, unscrupulous factions of the Catholic Church exploited the fear of the illiterate masses of the society as much as they could. As it was expected, after a while, people got tired of this racket and they eventually demanded to have more of a hand in their own salvation. This orientation led to the Lollard heresy in the $14^{\text {th }}$ century. Lollards wanted to be able to read and understand the Bible themselves. Then, they avoided accepting the Latin-only services and the Bible's interpretations provided by the church. They also wanted the church to desist from its crude and unrefined practices such as accumulating wealth and selling indulgences to earn money. But things did not go well for them as expected and many of them were burned at the stake for challenging the Church. The Catholic Church was also the center of education in Middle Age's society and for everyone who wanted to learn, it was the church (and attached schools) through which the learning was possible. Since church was the only main center of supplying education for people, it encouraged people to become cleric and use their education to serve the Church and put their learning to good use for them ( Fichtenau, 1992).

In addition to the religion as an influential factor that had great influence on the thoughts and literature of the Middle Age, another factor namely chivalry can be mentioned. According to Zeigler (2006), the chivalry was the system of values (such as loyalty and honor) that knights of the Middle Age were expected to follow. It was a code of conduct associated with a knight's behavior. This code of conduct placed limits on knights to protect and honor the weaker members of the society and helped the church maintain the peace. The chivalry form the content of some works such as Arthurian legends, king Arthur stories and Knights of the Round Table. Arthur was remembered as the Celtic/Roman leader who repelled the invading Anglo-Saxons. He was a fictional figure of the Middle Age. But, unlike King Arthur, the concepts of chivalry and courtly love were real. The word chivalry derived from the French word for horse (cheval) and horsemen. It indicated that chivalry was used only for knights and under the code of chivalry, the knights vowed to protect the vassals and lord in feudal society (Zeigler, 2006).

\section{Discussion and Conclusion}

In this study, the current researcher analyzed the relationship between religion and philosophy and investigated their influences on some of the literature content of Middle Age. The findings displayed that the Catholic Church was the only unifying force in whole Europe that was under the kingdom of Roman Empire In Middle Age. It remained the most powerful force and institution as well as the only center of learning at the end of the Roman Empire in Middle Age. Several good literary works of Middle Age were remained indicating the rich culture of the medieval people who produced many advances in art, literature, science, and medicine. The culture related development of medieval period paved the way for the ideas that would become the beginning of the Renaissance. As an example, Canterbury Tales of Chaucer is considered one of the greatest works created in Middle English. In this literary work, Chaucer used satire to depict the pilgrims in the "General Prologue" to reveal the prevalent corruption of the Church. Like the results of Alston's (1998), the present study reviewed some literary works and showed that most of the issues that the writers of Middle Age focused on were directly related to God, his existence or creative activity.

Out findings of the study are compatible with Fichtenau (1992) who stated that although all the events of life were attributed to the will of God, the writers of this period worked to create lyric poems and dramas related to Church and its role in society in which the people lived. Mother Julian of Norwich, for example, wrote about divine and the power and influence of God during the Middle Age ( Fichtenau, 1992). It was believed that sins are caused the people to be punished by God. Due to the existence of these beliefs, traces of religion and church can be easily found in the content of Middle Age's literature. In this study, viewpoints of different philosophy schools were examined. For example, we found out that the first medieval philosopher i.e. Augustine emphasized on achieving knowledge through divine illumination. Additionally, based on what was expressed by Fromm (1941), Augustine philosophy could lead human to attain moral goodness by just loving God. Tomas Aquinas (1225-1274) as another leading philosopher of Middle Age declared that we can reach the real and pure faith through reasoning. According to him, the reason can give us the required knowledge of God and His existence or creative activity.

As a conclusion, it worth mentioning that since medieval literature covers a period of about 1000 years, devoting just some pages of this paper to it may be odd. Absolutely, all cannot be said in just a few papers. Among all the issues through the Middle Age, some critical issues attracted much attention of the greatest philosophers from the Christian, Muslim and Jewish faith traditions. Briefly speaking, the first critical issue was the relationship between two controversial issues including faith and reason. In this relationship, the main cornerstone of significant religious and philosophical beliefs i.e. is it grounded on faith or reason? was looked for in some philosophical movements. To reach the answer, some philosophers started from the Athens and Greek schools of philosophy as the symbols of reason and 
most popular tradition of thinking in the world of that time. Additionally, representative of faith i.e. Jerusalem was also the center of most philosophers' attention to find out whether reason have to do with faith? One of the people who answered the question was Tertullian (155-230 CE) who was a strict proponent of faith-only position. He stated some anti-logic statements and declared that reason would impede our discovery of truth. Contrary to Tertullian, some other philosophers stated that the misleading matter of reason could be employed to demonstrate some religious truths that we also know through faith. The other most significant issue for medieval philosophers was to prove the existence of God. Since description of God by human language was considered a problem, many medieval philosophers argued that the problem of religious language could be challenging if we wanted to say meaningful statements on Him. The most common words to describe God were "powerful" and "good" in medieval literature.

\section{References}

Abrams, M. (1979). The Norton Anthology of English Literature. New York: Norton \& Company, Inc.

Algeo, J. (2010). The Origins and Development of the English Language. Boston: Wadsworth, Cengage Learning.

Alston, W. (1998). "History of Philosophy of Religion." The Routledge Encyclopedia of Philosophy. New York: Routledge.

Amodio, M. (2000). Tradition, Performance, and Poetics in the Early Middle English Period. Oral Tradition, $191-214$.

Baugh, A., \& Cable, T. (2002). A History of the English Language. London: Routledge.

Behtash, E. (2012). Interrelationships between Language and Literature from Old English to the Modern Period. Iranian Journal of Applied Language Studies, 4(2), 189-218.

Bennett, J., \& Smithers, G. (1968). Early Middle English Verse and Prose. Oxford: Oxford: Clarendon Press.

Fichtenau, H. (1992). Heretics and Scholars in the High Middle Ages, 1000-1200. Pennsylvania: Pennsylvania State University Press.

Foley, J. (1985). Oral-Formulaic Theory and Research: An Introduction and Annotated Bibliography. New York: Garland. Retrieved from www.oraltradition.org.

Foley, J. (2002). How to Read an Oral Poem. Urbana: University of Illinois Press. Retrieved from www.oraltradition.org.

Fries, C. (1940). "On the Development of the Structural Use of Word-Order in Modern English,” Language, 16, 199_ 208.

Fromm, E. (1941). Escape from Freedom. New York: Farrar \& Rinehart.

Gilson, E. (1931). The Spirit of Mediaeval Philosophy. New York: Charles Scribner's Son.

Gilson, E. (1938). Reason and Revelation in the Middle Ages. New York: Charles Scribner's Sons.

Horobin, S., \& Smith, J. (2002). An Introduction to Middle English. Edinburg: Edinburgh University Press Ltd.

Lucas, H. S. (1943). A Short History of Civilization. New York: McGraw-Hill book company, inc.

Malone, K. (1930). When Did Middle English Begin? Linguistic Studies, 110-17.

Miller, E., and Hatcher, J. (1978). Medieval England: Rural Society and Economic Change 1086-1348, London: Longman Group Limited.

Moore, S. (1927). Loss of Final $\mathrm{n}$ in Inflectional Syllables of Middle English, Language, 3, 232-259. HYPERLINK "https://doi.org/10.2307/409257" \t "_blank" https://doi.org/10.2307/409257 .

Moore, S. (1928). Earliest Morphological Changes in Middle English, Language, 4, 238-266. HYPERLINK "https://doi.org/10.2307/409140" \t "_blank" https://doi.org/10.2307/409140 .

Vivian, C. (1996). Chomsky's Universal Grammar and Second Language Learning, Applied Linguistics, 6, 2-18. .

Wallace, D. (1999). The Cambridge History of Medieval English Literature. Cambridge : Cambridge University Press. HYPERLINK"https://doi.org/10.1017/CHOL9780521444200"\t"_blank"

https://doi.org/10.1017/CHOL9780521444200 .

Weber, A. (1908). History of Philosophy. New York: Charles Scribner's Sons.

Whitehead, A. N. (1967). Adventures of Ideas. New York: The Free Press.

William, A. (1998). "History of Philosophy of Religion." The Routledge Encyclopedia of Philosophy. New York: Routledge.

Zeigler, E. (2006). Sport and Physical Education in the Middle Ages. Trafford. Retrieved from http://www.earlezeigler.com/ebook/sport_physicalActivity_in\%20_MiddleAge.pdf. 